\title{
The Essence of Pressure \\ of Globalization in Modern Times: the Socio-Philosophical Aspects of the Problem
}

\author{
Dmitry I. Kravtsov* \\ Siberian Federal University \\ 79 Svobodny, Krasnoyarsk, 660041, Russia
}

Received 23.01.2015, received in revised form 29.01.2015, accepted 09.04.2015

The article investigates an important scientific problem of our time, associated with all forms of modern globalization processes. The author emphasizes the particular manifestation of globalization pressures in the social field. The real opposition to such negative manifestations of contemporary globalization is, in my opinion, the social immune system. It is shown in the paper with a reference to historical traditions and the mentality of a particular society.

The term "global pressure" which acts as an important feature of globalization, as well as similar concepts of "planetary", "universal", "world" used in one way or another, since antiquity. However, the transition from the concept to the term, and then to the conceptual use of this term occurred relatively recently. It is noteworthy that in this connection many textbooks and dictionaries yet do not use the term "globalization", but when characterizing the subject and methods of global studies stress that this "scientific field, quickly finds signs of a new independent science". This underscores the novelty of this new direction of research.

The complex nature and dynamics of globalization pressure as an object of study and inevitable in this case, interdisciplinary significantly impede the establishment of clear boundaries of the test subject, as they often merge with other areas of knowledge: futurology, cultural studies and philosophy. In addition, the theoretical knowledge gained in global studies, are often associated with the need to take concrete decisions, which also determines the expansion of the frontiers of the subject.

Investigation of the features of the globalization pressure, as shown in this article is based on a desire to show the existence of globalization, its diversity, so this paper discusses the methodology of the study of different types of society, historical patterns of social structures, as well as from the standpoint of the stability of the objective and subjective determinants globalization pressures. All these provisions should be investigated for understanding one of the most important at the present stage problems: how the design of human activities in the context of globalization corresponds to co-evolutionary model, harmonious and sustainable human existence in the world.

Globalization pressures updated in the context of distinguishing between "natural globalization" or "globalization from below" and "managed globalization" or "globalization from above". The essence of "natural globalization" means the process of expansion of the world of man and culture, enriching its value concepts, natural familiarity and comprehension of diversity being one culture by another. "Metaphysical" essence of "violent", controlled globalization is that it is a policy directed from outside the universalization of achievements, which means the imposition of common values to the world community.

(C) Siberian Federal University. All rights reserved

* Corresponding author E-mail address: ymp1957@rambler.ru 
According to the author, a philosophical analysis of the nature of globalization pressure can help broaden the horizons of meaning of theoretical thought, a clear picture of the civilizational processes occurring in man and society in formation of a new post-industrial society. Categorical comparisons of globalization and internationalization, globalization and interpenetration of various (economic, social, financial, information, management, etc.) structures, globalization and information, etc. contribute to the conceptualization of this phenomenon, comprehension of its "metaphysical" nature at this stage of the development of civilization.

According to the author, the study of the concept of "globalization pressure" is methodologically fruitful that in this case specifically identifies two related but relatively independent components of the process of globalization, namely the increasing global interdependence of peoples and nations on the one hand, and awareness of the world as a whole - with the other. As a complex and multidimensional process of globalization has stimulated the emergence of a significant number of concepts that focus on various aspects of this controversial phenomenon.

The structure of the outlook can be represented in the unity of the four elements: the initial principle of systematization of knowledge about the world and man, method, or method of understanding the integrity, and the philosophical foundations of moral and ideological principles of a certain orientation. The system of universal community is based on the broadest sense and historical experience introduction, establishment and development of civilizations through time, space, and at different levels.

Keywords: globalization processes, pressure of globalization, social immune system, global studies, co-evolution, sustainable development.

Research area: philosophy.

One particularly relevant topics in modern social philosophy is the problem of the various manifestations of globalization, which is the natural foundation and determinants of violence, based on subjective interests of leading multinationals and countries. Actively discussed within this very broad topic questions about causes, essence, the beginning of globalization; its subjects and directions about the features of the global world; the interaction of cultures, on the structure of world order; the management of the international community and building a new world order. All this is to some extent related to the understanding of the essence of the globalization pressure, because currently we are witnesses of a unique confluence and weave of huge scale phenomena and processes, each of which individually might be called a milestone in terms of its consequences for all the international community and for particular people. The ongoing profound changes in the geopolitical structure of the world community and the transformation of social and political systems give grounds to speak about the end of a historical period and the introduction of the modern world in a qualitatively new phase of unsustainable development.

The term "global pressure" which acts as an important feature of globalization, as well as similar concepts of "planetary", "universal", "world" used in one way or another, since antiquity. However, the transition from the concept to the term, and then to the conceptual use of the term occurred relatively recently. It is worth of note in this connection that in many textbooks and dictionaries, yet the term "globalization" is not available, and in characterizing the subject and methods of global studies, they stress that this "scientific field, quickly finds signs of a new independent science". This underscores the novelty of this new direction of research.

Without a philosophical analysis of the numerous references to the term "globalization pressure" its categorical meaning is very vague and uncertain that has a different cause. Firstly, the uncertainty stems from the multidimensional processes, denoted by this term. Secondly, 
vagueness associated with movability of the processes covered by the term "globalization", and hence the various manifestations of globalization pressures. Third, at the present stage of development of human culture affects insufficient theoretical and philosophicalmethodological understanding of the processes captured in the language of globalism. Fourthly, discrepancies in the interpretation of globalization pressures arise from the specific ideological context understanding of the process when the global often is accompanied not only with planetary processes as to the processes that are associated with the transformation of Western industrial society and the desire to present global dynamics of socio-cultural processes in the West as a reflection of global processes.

Various extreme views on globalization pressures do not cover the whole range of existing views, the diversity of which is due not only to the complexity of the problem, but the lack of its drafting, which leads to negative consequences. In particular, the difficult communication between people is hampered by interdisciplinary interaction, create serious obstacles to understanding the true causes of globalization and the contradictions generated by it. Here lie the causes of many conflicts and misunderstandings arising from the fact that the world in their particular parts and the relationship becomes more unified, holistic, interdependent, while sufficiently effective mechanisms to regulate social relations at the global level, in the present conditions are absent [26].

The term "global pressure" received serious attention only since the late 90 -ies, when the focus of attention of scholars shifted from global issues to understanding the very phenomenon of globalization. By this time, they accumulated considerable theoretical and factual information in the field of planetary processes and phenomena, and the terms "globalism", "globalization”, "global world", “anti-globalization", "global problems", etc. became widely used not only in the scientific literature, the media, political and vocabulary, but also at the level of everyday speech. However, the problem is that although the basic meaning of these concepts at the level of general ideas is clear enough, but in the scientific environment of their content remains the subject of considerable debate: different scientists often put a different meaning in them. In particular, when studying the pressure of modern globalization, it is important to consider that the term "globalization" is used mainly to describe the integration and disintegration processes of the planetary-scale in the field of economy, politics, culture, and human-induced changes in the environment that shape the world and substantively affect the interests of the entire international community. In this part of the modern processes of social development are considered in isolation from their fundamental causes and the genesis, i.e. without taking into account the history of the formation and dynamics of international organizations and transnational ties. With this approach, the pressure of globalization is associated only with the events of the last century, and it is not considered as a consciously defined and controlled process, which is purposefully carried out by some policies. If we talk about globalization as a set of subjective reality projects in the interests of a certain group of people, transnational corporations or states, then we do not analyze the mechanism of globalization pressures that researchers emphasize [20].

Investigation of the features of the globalization pressure is based on a desire to show the existence of globalization, its diversity, so this paper discusses the methodology of the study of different types of society, historical patterns of social structures, as well as from the standpoint of the stability of the objective and subjective determinants of globalization pressures. All these provisions should be investigated for 
understanding one of the most important at the present stage problems: how the design of human activities in the context of globalization corresponds to the model of co-evolution, harmonious and sustainable human existence in the world.

"The global pressure" is a concept that is characterized by the relationship in a globalized world, in which there is non-constructive power to impose its value system for an object (country, region), place of harmonious mutual sharing of positive experience between the subjects of globalization. The concept of "global pressure" appears as the need to consider the complex dynamics of the changes in the development of socio-natural evolution that brought to humanity in all its evidence in the middle of the twentieth century and became an independent subject of scientific analysis. This concept originated in the framework of a systematic approach to the study examined trends [10].

The complex nature and dynamics of globalization pressure as an object of study and inevitable in this case, interdisciplinary significantly impede the establishment of clear boundaries of the test subject, as they often merge with other areas of knowledge: futurology, cultural philosophy. Apart from theoretical knowledge obtained in global studies, it is often associated with the need to take concrete decisions, which also causes expansion of the frontiers of the subject. In particular, foreign globalists originally developed two lines of "technocratic", whose members clearly exaggerated the positive impact of science and technology on society, and "techno-pessimistic" whose supporters blamed the negative effects of globalization on the scientific and technological progress, international capital and transnational corporations [7].

In our view, a full investigation of all manifestations of globalization pressure involves integrative approach. Global problems escalated in the late twentieth century, processes associated with integrative trends in science require further attention [15]. In particular, globalization pressure is updated in the context of distinguishing between "natural globalization" or "globalization from below" and "managed globalization" or "globalization from above". The essence of "natural globalization" means the process of expansion of the world of man and culture, enriching its value concepts, natural familiarity and comprehension of diversity being one culture by another.

There is no unity of views on various aspects of globalization pressure, due to the lack of a unified theory of globalization in general. The novelty of this phenomenon and insufficient knowledge of the topic suggest a certain necessity for its studies. However, the analysis of globalization pressure involves integrated efforts of scientists of different directions, because the level of general scientific methodology appears as an interdisciplinary approach. The essence of the interdisciplinary approach is the implementation of an integrated forecasting and drawing up a complete picture of the subject, passing stage of maturity in order to purposefully and creatively actively help it to achieve spiritual and moral, physical and professional and cultural levels in the public and state system. [12]

Studies of the concept of "globalization pressure" can be methodologically fruitful that while specifically identifies two related but relatively independent components of the process of globalization, namely the increasing global interdependence of peoples and nations on the one hand, and awareness of the world as a whole on the other. As a complex and multidimensional process globalization has stimulated the emergence of a significant number of concepts that focus on various aspects of this controversial phenomenon. 
"The study of the history of globalization pressure is one-sided" - V.E. Klochko stipulates in his article, stressing that science, divorced from its past, in principle, cannot meet the challenges of the future, unable to identify itself, and its presence in the present. [13] According to V.E. Klochko, there is a need to distinguish between "invocation" of the future, articulated scientific futurology and real "challenge" correlated with the possibility of an adequate response in the science, which was able to meet the challenges of the past. In other words, the methods of globalization pressures, despite the specific manifestations of contemporary globalization in general have a historical basis.

Globalization emerged from a cascade of proliferation and global market information. At the same time it generates an incredible gap in life and plans developed and less developed countries. In this regard, globalization pressure is based on the use of original data from various economic benefits that lead to political and cultural pressure.

Most authors agree on one thing: the pressure of globalization is fraught with various shocks and collisions. The most developed and powerful countries potentially tend toward socialDarwinian concept of a global world where the fittest expanding their opportunities by the less fit. An asymmetry between the two parts of the global world that threatens to split humanity adapted to the cultural and un-adapted race that owns the majority. Globalization pressures in this context reflect not only the specific features of the policy of governments, but also the mentality and involve consideration of the whole complex of modern problems: political, economic, social, cultural, technical, environmental, etc., which defines the term "global issues" [6].

The structure of the outlook can be represented in the unity of the four elements: the initial principle of systematization of knowledge about the world and man, method, or method of understanding the integrity, and the philosophical foundations of moral and ideological orientation. The system principles of universal community based on their broadest sense and historical experience introduction, establishment and development of civilizations through time, space, and at different levels. This is largely due to the fact that the current globalization processes and have a subjective aspect, concerning the moral and political foundations of our civilization. On this side of the essence of the processes can be defined by the term "geopolitics of globalization", the meaning of which is the conquest of power and strengthening the West over the rest of the world, a new world order and one world government. [28]

Objectivity of globalization implies a certain consistency, an important part of which becomes simulation of the future. However, a significant gap of numerous studies on objective grounds globalization is the lack of forecasts and scenarios of its further development. It should be noted that a number of authors in their works come to the level of modeling prospects of globalization. For example, V.G. Branskii and S.D. Pozharskii [5] believe that the most important predictions about the future of globalization is the conclusion that it will inevitably lead to the globalization of rights.

Globalization has affected the transformation of international political relations as the interstate in the "global" political relations, where there is a large part of the non-governmental. It is this non-state component that is represented by many scientists as key players in the "field of globalization". Thus, for the understanding of the globalization pressure it is important to consider that the management processes also tend to globalization and the emergence of a new type of management - global governance [4].

Exploring the objective determinants of globalization pressures, it is important to 
emphasize that the current process of European integration is a desire to weaken the lag in social development. For Western Europeans are united not because they felt sympathy for each other, but because they themselves alone they can not respond adequately to the general planetary challenges. The unification of Europe, which is the highest level of social integration, entail decentralization at the local level. Under these conditions, big nations will be forced to give up some of their powers and regional bodies get more rights. In the modern world the nation-state has ceased to be the only subject of international relations. Thus, there is an alignment not only the political weight of the different countries, but also created the objective conditions for the preservation and development of local sources of original sociocultural phenomena [22].

Modern objective determinants of globalization fit into the logic and sense of history, even though they are unprecedented in nature. The rise of modern globalization there is a coincidence of history with the new realities. According to V.G. Pantin, globalization will change to analogue disintegration, most likely it will be felt in 2050 [19].

Subjective availability depends on the will and desire of the people of globalization and implies an ideology, practices and mechanisms. A key mechanism of the form of globalization that we have is "consistent removal of all local interests, norms and traditions" [18]. Democracy, therefore, increasingly becomes a screen behind which hides a concerted strategy of international trusts, corporations and banks.

Description of the processes of globalization of the system shows a lack of unity among different authors in the choice of the original axiomatic. From the variety of beliefs and concepts. On the same processes of globalization, there are many competing views. In any case, it is important to bear in mind that, historically, the globalization is to some extent a continuation of the historical "neo-mondializm", the essence of which was reduced eventually to the postulation of the inevitability of complete planetary integration of the transition from a multiplicity of peoples, nations and cultures to uniformly world (one world) with a single world government and global governance [21].

Modern processes of globalization have a subjective aspect, concerning, moral and political foundations of our civilization. The essence of the processes can be defined by the term geopolitics of globalization, the meaning of which is the conquest of power and strengthening the West over the rest of the world, a new world order and one world government.

Striving to justify the pressure of modern globalization is an essential part Western ideology, which in its most extreme forms of aggressive outdated as brought to life by the attempts of the West to shift the solution of arising problems to other countries.

The most intransigent opponents of globalization believe that it is a sophisticated form of genocide. In globalization, they see a threat not only to Russia's national security, but also the degradation of social consciousness, fall of morality and a gradual loss of national identity. "The participation of the Russian Federation in the construction of a single global super-state, the advocates of such a radical point of view, does not correspond to the historical mission of Russia, which is a condition for maintaining its return to its own traditional principles of national existence. The future of Russia as a sovereign state, they say - in reliance on the intellectual and cultural potential of historically resistant forms of statehood on its own resources" [8].

Proponents of the concept, according to which the pressure of globalization is a consequence of actions of specific subjects, involves an analysis of the damage that causes such a policy: a) 
threatens the loss of national sovereignty; b) the threat of foreign intervention in the internal affairs of the country; c) strengthen American influence in the world; d) forcing other countries to make concessions to the United States. It is reasonable to fear those politicians who believe that one of the main threats to Russia's national security is the desire of certain circles of society to give up national interests for the sake of barren of hope for equal cooperation with the United States. According E. Todda, the current situation suggests that "if America tries to establish a Eurasian coalition of countries, although very different, but taken to the extreme randomness of US policy" [16].

The highest form of integration is the creation of so-called supranational bodies. In fact, it is just a politically correct euphemism, because no supranational bodies do not exist. As the prominent journalist M. Leont'ev rightly emphasizes: "Either it is not organs or they do not supranational. A cautionary example of this situation -Modern European Union" [14]. Eurasian Union - a political project; geopolitical, built on a natural, absolutely natural economic basis. In the "model" the European Union was originally the American will to consolidate Europe against the Soviet bloc and the US military-political roof.

Globalization pressures exercised its subjects, suggests that Western civilization has exhausted itself in the macro-evolutionary. That is the conclusion - the macro-evolutionary exhaustion of Western civilization - not only leads the bitter historical experience of Russians and Russian (or flashy international equities, as the bombing of Serbia, the occupation of Iraq, or the rejection of Belarus, and others.), And direct statements of the best Western minds (Heidegger, Derrida, Rorty, Pellegrino, Vattimo, etc.) - the "end of philosophy" (the end of Western philosophy, it is in the macro (the future of) evolutionary aspect) [25].
Awareness of the dangers of subjective determinants of globalization pressure involves consideration of the fact that the liberal state based on the principle of strong: can be anything that is not prohibited by law. " The right of the strong can both go and return to the necessary extent in all spheres of social life, i.e., the extent to which demands dictate strong. In turn, the conservative state - is concentration of forces of all social institutions in the matters to achieve a social ideal, the realization of the social contract, the implementation of the state ideology, creed, or national ideals, etc. The development of a world government, no matter how narrow or first would be its sphere of competence, already has and will continue to be similar to the process of formation of national states. In both cases, the main goal safety. Indeed, the main manifestation of the emerging new control system performs a sort of global police department, which is limited mainly to the fight against terrorism [27]. Globally, it is understood that Western consciousness has hopes of finding substantial-common for different cultures.

The subjective determinants of globalization pressures particularly visible at the level of international law. About undermining the philosophy of international law indicated creeping acceptance of the concept that the States are first and second grade ("rogue states") and classify them into groups declaring themselves that only "about" States are allowed to have weapons, and, finally, that "best" may punish the "worst". At the time this manifestation of liberal ideology, and, in fact, social Darwinism - the struggle of organisms for survival - has been condemned not only all Christian, but was still idealistic liberal human thought. The ethos of the war, in which the best people takes away from the road unhistorical - "worst", as the slogan "Deutschland, Deutschland über alles" (literally, Germany, Germany above all) was developed 
by the German historian Heinrich Gotthard von Treitschke in the days of Bismarck" [23].

In modern conditions there is a need to consider another important aspect that characterizes the subjective determinants of globalization pressures. An analysis of existing concepts of modern society leads to the conclusion that the conventional model of social order is the upgraded model of mass society. For many definitions of modern society as "industrial", "abundant", "democratic", "open", etc. I guess the same set of attributes. As such, they are the economics of mass production and consumption, the state mass democracy and mass parties, mass culture - the art and science being developed for the masses and the forces of the masses. Another attribute of modern society is the type of social stratification as a specific form of differentiation status, ordering of human relations. "Weight is differentiated into layers, depending on the level of income, consumption, education, skills, and other. The social status of an individual is determined not by its membership to the community - the clan, class or caste (prescribed status), and is the result of an individual assessment of his qualities and activities on universal criteria (achieved status)" [9].

The subjective determinants of globalization pressure manifested in the fact that the sociohistorical reality is the result of a symbolic construction. Type arising out of such actions of the global world order is described by the definitions of "hierarchical, authoritarian, US-centric, noninstitutionalized, informal" (the latter means nothing, as "globalization of concepts") "[1]. The subject determinants of global pressures lead to the ideology and practice global fundamentalism, which rejects the idea of the equality of nations and justifies neocolonialism, elevating the leading nations of the world to the level of the elite and the rest of the nations to come down to the level of serving the masses of this elite. Naturally, the "global fundamentalism" has created "antiglobalist fundamentalism". The fact that a necessary condition for the existence of the global identity is rigid segregation of the population into two unequal parts: the "select few" and "rejected by the majority." Such a strategy is the structure of the world destabilization and destructive in nature. For example, for the sake of implementing their own selfish understood "national" objectives of the United States have set themselves in the service of state terrorism. For the past 50 years the United States committed more than 30 acts of aggression against other countries, using the flimsy, and even frankly false pretexts. It is quite understandable that the traditional principles of American life, approved by the founding fathers of the country and the first settlers of the Protestant collapse under the pressure of ethnic minorities. Many US citizens no longer consider themselves Americans and begin to determine its identity by blood, by language, treats her as an African-American, Hispanic and others [24].

In modern democratic system of government elections are a kind of milestone for the people who lost the right to rule. Voters are candidates for "flock to collect votes", their capital base and power in society and employment. For example, one of the ideologists of monarchism K.P. Pobedonostsev was strongly against the idea of massive election [2], which is under the domination of the subjective determinants of globalization pressure is of particular importance.

That subjective determinants of globalization pressures pose the greatest dangers and threats for the modern world civilization in general, and Russia in particular. In the context of globalization, in which the interests of all countries, the West will need a deeper scientific understanding of how the fundamental laws of modern human development and taking into account religious, philosophical, cultural and moral peculiarities of 
the peoples of its components. Without such an attitude to the objective process of globalization of international relations can develop a unified system of human civilization.

For an adequate understanding of the subjective determinants of globalization pressure is necessary to differentiate the two different trends, two ways of development of modern civilization: globalization and globalism. Globalization reflecting universal, progressive, objectively necessary for the integration trend, carried out in order to create a single, global community in which the vital interests of all peoples and nations. Globalism is a social model imposed on the world political and economic dominance of Western civilization under the aegis of the United States [3].

The negative effects of globalization, largely due to the apparent lack of economic self-sufficiency of the United States - the main "globalizer" of modern times. Another reason is that most of the "Globalizer" developing countries is fundamentally unable to respond adequately to the challenges of globalization. In its development, the US economy has come a long way, however almost every stage was characterized by two fundamental points, each of which calls into question the right of the United States to be a leader of globalization processes. One of them is that the US economy has always developed extensive way. Another feature of the
US economy is that it has always evolved from borrowed funds. "The main" trouble of modern globalization is that its main protagonist was a country accustomed to use the world for their own selfish purposes, and therefore not able to really take care of the ongoing dynamics of its development" [11].

Multidimensionality, complexity of the process of globalization are difficult to predict due to its openness and non-linearity, which provokes certain subjects in the pressure of globalization, and calls the appropriate level of anti-globalization ideas and actions. Under these conditions, a serious threat to international security is becoming anti-Americanism, which in some cases takes a dramatic, anti-human character, and not yet fully eradicated racism and fascism [17].

Thus, a complete study of the globalization pressure, involves consideration of the characteristics of different societies, because the processes of globalization are multifaceted, that is, there are subjects and objects of globalization. To understand the features of globalization pressure is necessary to pay more attention to the evolutionary history, retrospective and predictive tasks. This dialectical approach provides the ability to comprehend the essence of the globalization processes and displays them in different areas of public life for both the whole humankind and individual nations.

\section{References}

1. Andreeva T.N., Kosolapov N.A. Iadernoe sderzhivanie v usloviiakh globalizatsii (politikopsikhologicheskie aspekty problemy) // Filosofskie nauki [Nuclear deterrence in the context of globalization (political and psychological aspects of the problem) // Philosophical Sciences]. 2005. № 9. Pp. 5-6.

2. Artem`ev E.R., Tiurin E.L. Problemy etiki demokraticheskikh vyborov // Vestnik Rossiiskogo filosofskogo obshchestva [Problems of ethics of democratic elections // Bulletin of the Russian Philosophical Society]. 2005. №2. Pp. 181-182.

3. Balakhonskii V.V. Globalizatsiia i globalizm v kontekste ugroz sovremennoi tsivilizatsii // Globalizatsiia: pro et contra: Materialy Mezhdunarodnoi konferentsii "Globalizatsionnii vyzov istorii 
na rubezhe tysiacheletii: prioritety rossiiskoi kul'tury i iskusstva"'[Globalization and globalism in the context of threats of modern civilization // Globalization: pro et contra: Proceedings of the International Conference "Globalization call history at the turn of the millennium: the priorities of Russian culture and art"]. SPb: Asterion, 2006. Pp. 33-34.

4. Barabanov O.Ya., Golitsyn V.A., Tereshchenko V.V. Global'noe upravlenie [Global Governance]. Moscow, 2006.

5. Branskii V.G., Pozharskii S.D. Globalizatsiia $i$ sinergeticheskaia filosofiia istorii [Globalization and synergistic philosophy of history] // ONS. 2006. №1.

6. Vasilenko I.A. Politicheskaia globalistika [Political globalism]. Moscow, 2000. Pp. 18.

7. Globalistika: Mezhdunarodnyi, mezhdistsiplinarnyi, entsiklopedicheskii slovar' [Global Studies: International, interdisciplinary, encyclopedic dictionary] / Ch. Ed. Mazur I.I., Chumakov A., Moscow, Saint-Petersburg, New York: Elima, Peter, 2006. Pp. 875-878.

8. Dzliev M.I. Natsional'naia bezopasnost' v globaliziruiushchemsia mire // Global'nye protsessy i ustoychivoe razvitie [National security in the globalizing world // Global processes and sustainable development] / Coll. Articles / Editor. Ed. Ursul A.D. Moscow: Publishing House RGTEU, 2011. Pp. 165-166.

9. Ivanov D.V. Virtualizatsiia obshchestva [Virtualization of the society]. St. Petersburg: "Petersburg Oriental Studies", 2000.

10. Il 'in I.V. Globalistika v kontekste politicheskikh protsessov [Global studies in the context of the political process]. Moscow: Publishing house of Moscow University, 2010. Pp. 37.

11. Inozemtsev V.L. Vesternizatsiia kak globalizatsiia i "globalizatsiia" kak amerikanizatsiia // Voprosi filosofii [Westernization as globalization and "globalization" as Americanization // Problems of Philosophy]. 2004. №4. Pp. 65-66.

12. Kalakov N.I. Metodologiia prognosticheskogo issledovaniia v globalistike (na materiale analiza prognozirovaniia sotsial'no-obrazovatel'nykh protsessov) [The methodology of prognostic studies in Global Studies (based on the analysis of forecasting of social and educational processes)]. Moscow: Academic Project; Culture, 2010. Pp. 76-77.

13. Klochko V.E. Fenomen L.S. Vygotskogo: psikhologiia pered vyzovom proshlogo/V.Ye. Klochko // Psikhologiia pered vyzovom proshlogo: Materialy nauch. konf. priurochennoi k 40-letnemu iubileiu fakul'teta psikhologii MGU [The phenomenon of L.S. Vygotskii: psychology facing the challenges of the past / V.E. Klochko // psychology facing the challenges of the past: scientific materials. Conf. dedicated to the 40th anniversary of the Faculty of Psychology of Moscow State University (23-24 November 2006)]. Moscow: MSU, 2006. Pp. 33-34.

14. Leontiev M. Rossiia mezhdu soiuzom i parapolitikoi [Russia between the Union and parapolitics // Odnako]. 2011. 19 December.

15. Los' V.A. Ot globalizatsii nauchnogo znaniia $k$ globalistike: // Global'nye protsessy $i$ ustoychivoe razvitie [From the globalization of scientific knowledge to the global studies: // Global processes and sustainable development] / Coll. Articles / Editor. Ed. Ursul A.D.- Moscow: Publishing House RGTEU, 2011. M., 2011. Pp. 46.

16. Maksimenko V.I. Geopoliticheskoe izmerenie istorii $i$ sredneaziatskii vopros (otvet opponentam) [The geopolitical dimension of history and Central Asian question (answer to opponents) ]// East (ORIENS). 2002. №4. Pp. 74-75. 
17. Osipov G.V. Sotsiologicheskoe ponimanie novykh geopoliticheskikh i sotsial'nykh realii v 21 veke // Vestnik RFO. [The sociological understanding of the new geo-political and social realities in the $21^{\text {st }}$ century // The Bulletin .of RFO] 2005. №3. P. 35.

18. Panarin A.S. Iskushenie globalizmom [Temptation of globalism]. Moscow, 2000. P. 6.

19. Pantin V.G. Tsikly ivolny global'noi istorii Dokladna seminare "Filosofsko-metodologicheskie issledovaniia protsessov globalizatsii". Sektsiia "Globalistika” // Vestnik Rossiiskogo filosofskogo obshchestva [Cycles and waves of the global history Report on the seminar "Philosophical and methodological study of the processes of globalization". Section "Global Studies" // Bulletin of the Russian Philosophical Society. 2005. №4. P. 127.

20. Pfanenshtil I.A. Sovremennyi global'nyi mir $i$ al'ternativnye proekty razvitiia /I Innovatsionnye protsessy v sovremennom obrazovanii Rossii kak vazhneishaia predposylka sotsial'noekonomicheskogo obshchestva i okhrany okruzhaiushchei sredy: sb. statei Vseross. nauch.-prakt. konf. $s$ mezhdunar. Uchastiem [Modern global world and alternative development projects // Innovative processes in modern Russian education as the most important prerequisite for socio-economic society and the environment: Articles of All-Russian scientific and practical. Conf. with int. participation]. Krasnoyarsk: Siberian Federal University Press, 2011. Pp. 88-92.

21. Ramfal Sh. Neobkhodima politika obespecheniia mirovogo poriadka [Policies are needed to ensure world order] Internationale Politik. Global Governance. 1998. №11. P. 30

22. Simonian A.D. Ot natsional'no-gosudarstvennykh ob"edinenii k regional'nym // Voprosy filosofii [From the national to the regional state associations // Problems of Philosophy]. 2005. № 3. Pp. 25-26.

23. E. Stiglitz Globalizatsiia $i$ ee razocharovanie [Globalization and its disappointment] // POLIT. RU. 2004. 27 of January. Available at http: www.polit.ru

24. Fedotova V.G. Faktory tsennostnykh izmenenii na Zapade $i$ v Rossii. // Voprosy filosofii [Factors of value changes in the West and in Russia. // Problems of Philosophy]. 2005. № 11. Pp. 7.

25. Khrutskii K.S., Samarin A.G. Rossiiskii elektronnyi filosofskii zhurnal zhurnal dlia Rossii i dlia budushchego Rossii // Vestnik Rossiiskogo filosofskogo obshchestva [Russian philosophical electronic magazine the magazine for Russia and for the future of Russia // Bulletin of the Russian Philosophical Society]. 2005. №2. P. 187.

26. Chumakov A.N. Predmet globalistiki // Global'nye protsessy i ustoichivoe razvitie [The subject of global // Global processes and sustainable development] / Coll. Articles / Editor. Ed. Ursul A.D Moscow: Publishing House RGTEU, 2011. Pp. 25-26.

27. Etzioni A. Ot imperii k soobshchestvu: novyi podkhod k mezhdunarodnym otnosheniiam [From Empire to Community: A new approach to international relations]. Moscow: Ladomir, 2004. P. 2.

28. Iatsenko M.P. Globalizatsiia kak forma organizatsii istoricheskogo protsessa // Izvestiia Rossiiskogo gosudarstvennogo pedagogicheskogo universiteta im. A.I. Gertsena [Globalization as a form of historical process // Proceedings of the Russian State Pedagogical Herzen University]. №111: scientific journal. 2009. Pp. 109.

29. Iatsenko M.P. Istoricheskie aspekty globalizatsii kak upravliaemogo protsessa // Izvestiia Rossiiskogo gosudarstvennogo pedagogicheskogo universiteta im. A.I. Gertsena [Historical aspects of globalization as a managed process // Proceedings of the Russian State Pedagogical Herzen University]. №110: scientific journal. 2009. P. 102. 


\title{
Сущность глобализационного давления современности: социально-философские аспекты проблемы
}

\author{
Д.И. Кравцов \\ Сибирский федеральный университет \\ Россия, 660041, Красноярск, пр. Свободный, 79
}

\begin{abstract}
В статье исследуется важная научная проблема современности, связанная со всеми проявлениями глобализационных процессов современности. Автор особо подчеркивает особенности проявления глобализационного давления в социальной области. Реальным противодействием подобным негативным проявлениям современной глобализации выступает, по мнению автора, социальный иммунитет. Он, как показано в статье, базируется на исторических традициях и менталитете конкретного соииума.
\end{abstract}

Термин «глобальное давление» как важная характеристика глобализаиии, равно как и близкие к нему понятия «планетарный», «общечеловеческий», «мировой» употребляются в той или иной мере начиная с античности. Вместе с тем переход термина к понятию, а затем и концептуальному использованию данного понятия произошел относительно недавно. Характерно в этой связи, что во многих учебниках и словарях еще отсутствует термин «глобализачия», а при характеристике предмета и методов глобалистики подчеркивается, что это «научное направление, быстро обретающее признаки новой самостоятельной науки». Тем самым подчеркивается новизна и становящийся характер нового исследовательского направления.

Сложный характер и динамика глобализачионного давления как объекта исследования и неизбежная в этом случае междисииплинарность значительно затрудняют установление четких границ исследуемого предмета, поскольку они нередко сливаются с другими областями познания: футурологией, культурологией, философией. Кроме того, теоретические знания, получаемые в глобалистике, зачастую оказываются связанными с необходимостью принятия конкретных решений, что также обусловливает расширение грании обсуждаемого предмета.

Исследование особенностей глобализационного давления, как показано в статье, имеет в своей основе стремление показать все проявления глобализации в ее многообразии, поэтому в данной статье рассматривается методология исследования различных типов общества, исторических закономерностей развития общественных структур, а также устойчивости с позиций объективных и субъективных детерминант глобализационного давления. Все эти положения необходимо исследовать для понимания одной из важнейших на современном этапе проблем: насколько проектирование человеческой деятельности в условиях глобализачии соответствует модели коэволючионного, гармоничного и устойчивого существования человека в мире.

Глобализаиионное давление актуализируется в разрезе различения «естественной глобализации», или «глобализации снизу», и «управляемой глобализации», или «глобализации сверху». Суть «естественной глобализации» означает процесс расширения мира человека и культуры, обогащения его ценностных представлений, естественное знакомство и постижение многообразия бытия одних культур другими. «Метафизическая» суть «насильственной», управляемой глобализации состоит в том, что это политика направляемой извне универсализации достижений, что означает навязывание единых иенностей всему мировому сообществу.

Как утверждает автор статьи, философский анализ природы глобализационного давления может помочь расширить смысловые горизонты теоретической мысли, более четко представить цивилизационные прочессы, происходящие в человеке и соииуме в период формирования нового постиндустриального общества. Категориальные сопоставления 
глобализации $и$ интернационализации, глобализащии $u$ взаимопроникновения различных (экономических, социальных, финансовых, информационных, управленческих и т.д.) структур, глобализации и информатизачии и т.д. способствуют конщептуализации данного явления, постижению его «метафизической» сущности на данном этапе развития циивилизации.

По мнению автора, исследование понятия «глобализационное давление» методологически плодотворно тем, что при этом специально выделяется два взаимосвязанных, но относительно самостоятельных составляющих процесса глобализаџии, а именно возрастающая глобальная взаимозависимость народов и стран, с одной стороны, и осознание мира как иелого, - с другой. Будучи сложным и многомерным, процесс глобализачии стимулировал появление значительного числа конщепџий, которые делают акцент на те или иные аспекты данного противоречивого явления.

Структура миропонимания может быть представлена в единстве четырех элементов: исходный принцип систематизации знаний о мире и человеке, способ или метод постижения целостности, философские основания и нравственно-мировоззренческая установка. Системные принципы развития универсального сообщества основаны на их широком понимании и историческом опыте появления, становления и развития цивилизаций во времени, пространстве и на разных уровнях.

Ключевые слова: глобализационные прочессы, глобализаџионное давление, социальный иммунитет, глобалистика, коэволюиия, устойчивое развитие.

Научная специальность: 09.00.00 - философские науки. 